\title{
Professional profile of the distance education expert
}

\section{Perfil profesional del experto en educación a distancia}

\author{
RIVERA-GUTIÉRREZ, Erika†** \& HIGUERA-ZIMBRÓN, Alejandro \\ Universidad Autónoma del Estado de México, Centro de Investigación en Arquitectura y Diseño
}

ID $1^{\text {st }}$ Author: Erika, Rivera-Gutiérrez / ORC ID: 0000-0001-6966-2721, Researcher ID Thomson: AAJ-7948-2020, SNI CONACYT ID: 247442

ID $1^{\text {st }}$ Coauthor: Alejandro, Higuera-Zimbrón / ORC ID: 0000-0002-7851-753, Researcher ID Thomson: AAJ-7550-2020, SNI CONACYT: 226412

\begin{abstract}
The purpose studio is to present a referential framework focused on defining what is the professional profile of distance education expert, a specialist in higher education. For this, a qualitativedescriptive methodology will be used, based on literature scientific review, as well as empirical studies. To achieve, first the perspective of the field in the current labor market will be described. Second, the most common activities will be defined. Third, an interview process will be presented to fill the position. Fourth, the prospective of the field of work will be determined. Finally, the final considerations of this document will be outlined.
\end{abstract}

\section{Competences, Distance Education, Professional Profile}

\section{Resumen}

El propósito del estudio es presentar un marco referencial centrado en definir cuál es el perfil laboral para un profesional de la educación a distancia, especialista en la educación superior. Por tanto, se utilizará una metodología cualitativa-descriptiva, a partir de la revisión de la literatura científica, así como de estudios empíricos. Para lograrlo, primero, se describirá la perspectiva del campo en el mercado laboral actual. Segundo, se definirán las actividades más comunes. Tercero, se presentará un proceso de entrevista para ocupar el cargo. Cuarto, se determinará la prospectiva del campo de trabajo. Por último, se esbozarán las consideraciones finales.

Competencias, Educación a Distancia, Perfil Professional

Citation: RIVERA-GUTIÉRREZ, Erika \& HIGUERA-ZIMBRÓN, Alejandro. Professional profile of the distance education expert. Journal of Human Resources Training. 2020. 6-17: 10-19.

\footnotetext{
* Author Correspondence (mariluea@uttlaxcala.edu.mx)

$\dagger$ Researcher contributing as first author.
} 


\section{Introduction}

Currently there are several titles that are used within the workplace to refer to the instructional technology and design specialist (IDT), such as instructional designer, technologist, strategic and learning consultant, virtual environment specialist, instructional developer, education specialist, developer media, trainer, instructional systems specialist, to name a few. However, there are differences in the description of responsibilities in the workplace, which depend on the field in which they focus, educational, industry, business, consulting or militia. However, variations do not only exist in the jobs sought, but also in the expectations of the organizations for which they will work.

Hence, RTD should be seen as an emerging professional (Rothwell \& Kazanas, 2015), focused on leading education and training organizations in improving teaching and learning through the applications of educational technology. Therefore, the purpose of this document is to present a referential framework focused on defining what is the job profile for a distance education professional, a specialist in higher education. For this, a qualitativedescriptive methodology will be used, based on the review of the scientific literature, as well as empirical studies. To achieve this, first, the perspective of the field in the current labor market will be described. Second, the most common activities will be defined. Third, an interview process will be presented to fill the position. Fourth, the prospective of the field of work will be determined. Finally, the final considerations will be outlined.

\section{Development}

\section{Perspective of the Current Labor Market of the Field}

RTDs are currently contracted by business, industry, and higher education organizations. However, each RTD position has different responsibilities and expectations. In addition to strengths and weaknesses depending on their preparation and experience. Therefore, to be able to speak from the perspective of the current labor market of the field, it is necessary to define the professional profile (PP) regardless of the context in which it works.
On the one hand, Coll and Moreneo (2008), as well as Vargas (1996) refer to the PP, as the set of competences where the individual has the ability to put their knowledge, skills, experiences and personal characteristics into full use. in a certain position. On the other hand, the International Board of Standards for Training, Performance and Instruction (IBSTPI) (2012) developed a set of internationally recognized competences for RTDs. These focus on: (a) professional foundations; (b) planning and analysis; (c) design and development; and (d) implementation and management. Therefore, professional development for RTDs establishes the application of research and theory to the discipline, as well as updating and improving knowledge, skills and attitudes regarding the instructional design process and its field of application.

Furthermore, the Association for Educational Communications and Technology (EGTC) defines IDT as a learning facilitator, which improves performance through the creation, application and administration of technological processes and resources (as cited in Januszewski \& Molenda, 2008 ). Consequently, the instructional technology and design specialist is a professional who has the ability to facilitate and improve the educational process through theory, planning, analysis, design, development, implementation, evaluation, and management, supported by instructional methods, materials, and technological resources.

That said, to address the perspective of the labor market of a RTD in higher education, it is necessary to consider what Valente and Varela (as cited in Sánchez-Olavarría, 2014) point out, who need to assess the quality of an individual's professional profile Three aspects must be considered: (a) professional training, (b) professional performance, and (c) labor market demand. These have become indicators that show how higher education institutions (HEIs) respond to the dynamic demands of the labor market (Sánchez-Olavarría, 2014).

On the one hand, the quality in the training of an RTD professional does not only rest on the theoretical and technical aspects, but also on the pedagogical framework under which technology is inserted and used didactically. 
In this sense, the knowledge, perceptions and attitudes that one has about the media will become determining factors for their integration in the training process. Hence, Cabero (2006) points out that various factors must be taken into account in this training such as: (a) presentation of content; (b) synchronous and asynchronous communication tools; (c) teaching-learning strategies; and (d) use of technological materials.

Furthermore, Navarro (as cited in García, 2014) states that the IDT should focus on the use of Web 2.0, as a means and resource for carrying out these activities, taking into account virtual learning spaces for education, blogs, wikis, podcasts, e-books, virtual classrooms, among others. Therefore, the quality of RTD training must take into account all these aspects that enable knowledge, interaction, communication and information mediated by technological contexts.

On the other hand, the professional profile in job performance refers to the competencies (behaviors, abilities and knowledge) that people are expected to demonstrate that they are successful in their profession (Diaz-Barriga, 1999). In this sense, the Association for Talent Development (ATD) (Rothwell \& Kanazas, 2012), carried out a study by designing and implementing a mixed method, with the purpose of determining the key actions in the successful performance of the IDT. To do this, 26 RTD employers were interviewed, in addition to 1,381 professionals linked to the field.

Where the actions that are commonly performed were pointed out:

(a) Conduct the needs assessment (76\%).

(b) Design study plans, programs and problem solving $(80 \%)$.

(c) Identify appropriate learning approaches $(82 \%)$.

(d) Collaborate with the productive sectors $(76 \%)$.

(e) Design instructional materials $(80 \%)$.

(f) Develop instructional materials (74\%).

(g) Apply learning theories (68\%). (h) Evaluate the learning design (72\%).

(i) Analyze, select and integrate technological resources $(51 \%)$.

As can be seen in the study, all the tasks are important for the participants, even when analyzing, selecting and integrating technological resources obtained the lowest percentage. While the most prevalent action focuses on the design and needs of the learner. Activities that are directly linked to the current practice of the RTD expert in higher education, focused on the search for various job profiles (Campbell, Schwier \& Kenny, 2009), for example: instructional designer, teaching designer, project manager, consultant Educational, Instructional Development Consultant, Education Program Designer, Learning Consultant, Education Analyst, Educational Technology Manager, Learning Management Systems Preparation Coordinator, Curriculum Developer, Instructional Facilitator, Program Manager, Technology Specialist educational, technology coordinator, educational technology specialist, media developer, course designer, course developer, educational researchers, instructor, among others. Indeed, there is a diverse field of work in which RTD professionals can participate.

With regard to the RTD labor market demand analysis, it provides an in-depth understanding of the employment situation of higher education professionals linked to the field of information technology and telecommunications (ICT). On the one hand, in Mexico during the first four months of this year, only 295,000 people work within the ICT area, of which only $3.7 \%$ are in jobs within upper and upper secondary education (STPS-INEGI, 2020). On the other hand, a study on the employment situation of professionals in the information technology sector in Spain (CCII, 2015) is taken as a reference, considering that similar studies with scientific validity are not yet available in Mexico. The results show that the level of employment of RTD graduates and professionals is very high. Where, the higher their academic training, the higher their level of employment. However, there are employment opportunities in the medium term, in basic, middle and higher education. Likewise, the results show an unmet demand for RTD professionals, derived from a lack of skills in both a second language and behavioral skills. 
In short, the perspective of the labor market of a RTD in higher education is considered in three aspects. On the one hand, his professional training, focused on having the necessary skills that allow him in the educational process, plan, analyze, design, develop, implement, evaluate and manage, through the application of instructional methods, materials and technological resources. Aspects that are complemented by what Cariaga (2020) points out when he mentions that the "set of knowledge, skills and attitudes necessary to promote student learning in an increasingly technological world must also be considered, emphasizing the need to adapt the educational context to the world posed by technologies "(p. 7).

Likewise, a clear description of the professional profile for their job performance in the selected educational field. On the other hand, the supply of the labor market that considers their competences, placing them appropriately in the scope of performance in question.

\section{Responsibilities of an IDT}

Within the work environment in which an RTD is carried out, a series of functions are established that derive from their professional competences and the context in which they are found. In this sense, it is relevant to mention that the EGTC (as cited in Yeaman, Eastmond \& Napper, 2008) proposes 16 professional RTD skills focused on:

(1) Identifying projects for instructional development.

(2) Develop evaluations of procedures and instruments; as well as the interpretation of results.

(3) Create plans for evaluating the entry skills and attitudes of learners and instructors.

(4) Analyze work structures, activities and content.

(5) Establish learning objectives.

(6) Analyze the conditions and characteristics of the instructional environment, identifying the resources of the institution.

(7) Select sequential processes to guarantee learning.
(8) Determine instructional strategies.

(9) Establish a sequence of learning activities, according to the context.

(10) Evaluate, adapt or, if appropriate, propose the acquisition of instructional resources (means), as well as the production of instructional materials.

(11) Plan, conduct, and evaluate instructional and training processes.

(12) Design courses, training programs, and workshops for managing educational systems.

(13) Plan and monitor instructional development projects.

(14) Carry out effective communication (visual, oral and written).

(15) Leadership to work as a team.

(16) Promote the dissemination and adoption of instructional development processes.

In this sense, Seels (as cited in Vargas, 1996) considers that to describe the responsibilities of an RTD, the design, development, use, administration and evaluation must be considered; taking into account that they are the areas of competence of RTD professionals. In design, focused on determining learning aspects. Development, focused on changes in the instructional media.

The use, in the use of processes and resources to learn. Administration, in controlling technology and instructional design through planning, coordination, and supervision. The evaluation, focused on projects, programs and products. Vargas (1996) points out that through these five domains, both knowledge and application are integrated to solve problems. (Theory and Practice) of an RTD Professional. From the above, it is evident that the responsibilities of a RTD in higher education will depend on the actions of their professional competences (Saettler, 1990, as cited in Januszewski, 2001), as well as on the impact they have with respect to the process teaching learning. 
To exemplify the above, the organization manual of the UAEM's Continuous and Distance Education Directorate (2011) will be taken as a reference. To do this, some of the functions that are linked to a professional in RTD will be described. On the one hand, the distance education coordinator must: (a) coordinate the planning, organization, supervision and evaluation of distance education (EaD); (b) supervise the design and preparation of teaching materials; and (c) promote the training of material designers. The content manager must: (a) manage and supervise the creation of projects, programs and courses in distance or mixed modalities; (b) establish guidelines and procedures for planning, instrumentation and evaluation of educational programs or courses in any modality; (c) define guidelines and processes for the design of educational materials; (d) establish methodologies for the training of consultants, material designers, instructors and tutors in any modality. The pedagogical manager must: (a) develop pedagogically the proposals and practices of the teaching-learning processes built by the teachers and the content manager; (b) work collaboratively with the content manager; (c) monitor and evaluate compliance with the pedagogical structure of the educational proposals of the coordination. The manager of the learning unit must: prepare didactic resources mediated by ICT, in accordance and relation to what has been developed by the content manager and the pedagogical manager. Therefore, the importance of the responsibilities inherent to the position of an RTD is clarified, based on the competencies that in higher education should be considered as an expert in this area.

\section{Interview Process to fill the position}

In all organizations, protocols are followed for the recruitment and selection of personnel, with the objective of making the administration of human resources efficient. Through the application of techniques and instruments that facilitate the hiring of personnel with a professional profile and based on the legal requirements established by it. Higher education institutions are no exception. In this sense, for the recruitment and selection of a professional in RTD, the procedure established by Chiavenato (2000) is taken as a reference.
It should be noted that in the recruitment stage, candidates potentially trained to fill a vacant position are identified and interested (Peña, 1993). Job descriptions provide the basic information about the roles and responsibilities that each job includes. Therefore, Chiavenato (2000) mentions that there are two types of recruitment: (a) internal, the organization tries to fill the vacancy by relocating employees, it does not consider external bodies; (b) external, it is assisted by means of communication abroad. After recruitment, the selection process continues, which is not an end in itself, but a means for the institution to effectively achieve its objectives (Chiavenato, 2000). Where, the only competitive advantage that can differentiate her from another is her human talent, which is achieved through an efficient selection process (PS). Therefore, the staff selection and recruitment process begins the moment a vacancy arises for a current or new position for an IDT professional. So the PS for an IDT contemplates a series of phases:

1. Establish requirements. It refers to detecting and analyzing the needs for hiring an IDT in the higher education institution.

2. Define the job profile. It focuses on the job description for the IDT.

3. Recruitment. It focuses on establishing the type of recruitment and the means for recruiting candidates.

4. Interviews. A formal and deep conversation is carried out that allows evaluating the suitability of the applicant, based on the previously defined job description. Two interviews are carried out. One led by the human resources area and the other by the immediate future boss. It is in this phase, where the candidate must be able to highlight those competences that they possess and that are useful for the position offered. The main idea is that you can focus on developing personal marketing during the selection process, selling yourself correctly.

5. Tests. Knowledge or skills, psychological and personality tests will be applied. 
6. Preparation of reports. All information is carefully reviewed and compared to the job description. The selection results are evaluated with indicators established by the institution. Likewise, the candidates' reports are prepared and who will occupy the position is defined.

7. Final interview. Two interviews are carried out with the selected person, one directed by the human resources area and the other by the immediate future boss.

For all of the above, the provision of human resources (recruitment and selection of personnel) (Chiavenato, 2000) in higher education institutions should be a process that is adaptable and flexible to the needs of the position. It must also be participatory, where the people directly related to the vacancy being promoted collaborate in the suitable selection of the professional RTD profile to occupy the respective position.

\section{Prospect of the Labor Camp}

In order to address the prospective of the field of work of professionals in RTD, it is necessary to define the term prospective. In this sense, etymologically prospective comes from the word prospectus, which means looking forward, that is, it allows us to visualize the future and act in the present (Rivera \& Malaver, 2010). The Organization for Economic Cooperation and Development (OECD) (as cited in Colocho, 2017) refers to it as "the set of systematic attempts to observe the future of science, technology, economy and society in the long term with the purpose of identifying emerging technologies that are likely to produce the greatest economic or social benefits" (p. 2).

Likewise, Luke Georghiou (as cited in Hartmann, 2011), describes it as "a systematic means of evaluating scientific and technological developments that could have a strong impact on industrial competitiveness, wealth creation and quality of life" ( p. 335). Consequently, foresight not only aims to know in advance the future of science, technology, economy and society, to identify the impact of new technologies on society, but to design and build it in a collective and participatory way.
In turn, the predominance of knowledgebased economies is demanding that higher education institutions in Mexico expand their coverage to train a greater number of competent professionals, technicians, scientists, and humanists. However, access to higher education at different levels (undergraduate and graduate) is still limited. It should be noted that educational coverage refers to the percentage of students, who according to their age must be enrolled in an educational level (UAEM, 2019). Today, the coverage of higher education in Mexico is $35.8 \%$ of the population between 19 and 23 years, that is, only 34 out of every 100 young people of college age can do so (SNIE-SEP, 2019).

While the average in Latin America and the Caribbean is $42.8 \%$ and in OECD countries it is $71.4 \%$ (INEE, 2015). However, the coverage goal proposed in the National Development Plan 2019-2024 in Mexico, establishes among its objectives, to ensure greater coverage, inclusion and educational equity in higher education, for a fairer society, reaching $50 \%$ in the year 2024. Consequently, coverage should be increased in order for more young people to complete their university studies. In particular, in the state of Mexico, educational coverage is not far from the national situation. The population between 19 and 23 years old, for the 2019-2020 school year was $1,493,271$ young people. Where, the enrollment was 441311 , with a coverage of only $29.6 \%$. It should be noted that the Autonomous University of the State of Mexico (UAEM) has an enrollment of 55,489 young people, with coverage of $6.9 \%$. Based on these figures, it becomes evident that educational coverage in the state of Mexico is only 34\% (UAEM, 2020). That is why, to increase educational coverage, human, economic, technological resources, infrastructure and equipment will be needed, but primarily agreements between the actors involved and the improvement of teachinglearning processes in HEIs. This will allow planning of the educational offer and the closing of gaps at this educational level. For all of the above, the prospective of the professional field of RTD in higher education focuses on areas of opportunity that derive from the insufficient coverage that occurs at this educational level: (a) distance academic programs; (b) digital teacher training; and (c) development of technological material and resources. 
Distance academic programs (PAD). The scope of performance of the IDT will be in the planning, design, development, implementation and evaluation of quality PADs. Including equipment, infrastructure and technology for the operation of the PADs.

Teacher training (CD). The IDT professional will have the opportunity to train and update the teaching staff, as facilitator in the planning, design, development, implementation and evaluation of the programs of the learning units.

As well as, in the creation of learning communities in its different modalities, allowing the development of a solid teaching staff, which participates in consultancies, tutorials and digital design, acquiring the skills for the production of digital materials.

Materials and technological resources (MRT). The IDT will be able to focus on the design and development of audiovisual and multimedia materials in support of PADs. In addition to being a manager for the implementation of technology in classrooms and in virtual learning environments (EVA) or learning management systems (SGA).

Definitely, for higher education institutions to operate their PADs, they must contemplate a digitized administration. Therefore, it is necessary that technology constitutes the element through which all the processes included in digital systems are developed.

Where, the IDT professional participates as manager, leader, guide and facilitator in the operation of institutional substantive and adjective functions.

As well as in its ability to "guide and guide the constructivist mental activity of its students, to whom it must provide pedagogical help through the different media of communication and interaction, in accordance with the discipline that is going to teach "(Cifuentes-Medina, González-Pulido, \& González-Pulido, 2020, p. 9).
In addition, the distance study modality will allow expanding the opportunities offered by higher level education to more and more applicants. In particular, those who, due to their residence or work occupation, find it difficult to travel to educational institutions, in addition to allocating certain hours a day to attend classes.

\section{Conclusions}

The purpose of this study focused on exposing a referential framework that would allow defining the job profile for a distance education professional, a specialist in higher education. Therefore, after having defined the job profile of a RTD in higher education, it was possible to delineate the perspective of its labor market through a series of indicators that are considered to assess the educational quality of HEIs.

Likewise, the process for the provision of an RTD human resource was described, which does not differ from the standards that are handled by the human resources departments of any organization. Each of the aspects contemplated in the document made it possible to visualize the prospective of the field of the IDT professional, from the point of view of educational coverage in HEIs, as pointed out by Rivera \& Malaver (2010), to look ahead.

Therefore, the job profile of a professional in RTD, specialist in higher education is very broad. However, it is emphasized that the RTD must be constantly updated, in such a way that it has the competences that are demanded of it in a given position, as well as acting ethically in the work environment.

From a global vision linked to social problems, where everything is visualized as a system (Senge, 2016). In other words, establish a network of relationships that allow you to understand, understand and study these relationships to identify the essential variables required in the job profile for a distance education professional, a specialist in higher education. Without leaving aside, that the contributions to the field of Instructional Technology and Distance Education are in their hands and it is they who should strengthen the discipline through research and their professional work. His future is encouraging considering that his field of work is fertile ground to promote the benefits of distance education at the higher level. 


\section{References}

Cabero, A. J. (2006). Bases pedagógicas del elearning. RUSC. Universities and Knowledge Society Journal. Recuperado el 8 de julio de 2017 de http://www.redalyc.org/articulo.oa?id=7803010 2>

Campbell, K., Schwier, R. A., \& Kenny, R. F. (2009). The critical, relational practice of instructional design in higher education: an emerging model of change agency. Educational Technology Research and Development, 57(5), 645-663. Recuperado el 11 de julio de 2017 de https://link.springer.com/article/10.1007/s11423 $-007-9061-6$

Cariaga, R. (2020). Un marco teórico para analizar el rol docente en entornos de aprendizaje virtualizados. Recuperado el 06 de junio de $2020 \quad$ de http://rdi.uncoma.edu.ar//handle/123456789/15 694

Chiavenato, I. (2000). Administración de recursos humanos ( $5^{\mathrm{a}}$ ed.). México: McGrawHill. Recuperado el 12 de julio de 2017 de http://s3.amazonaws.com/academia.edu.docum ents/43099694/Chiavenato.pdf?AWSAccessKe yId=AKIAIWOWYYGZ2Y53UL3A\&Expires= 1499963368\&Signature $=$ bn5dpp8EM5aPDzw6 xoEXHDIZpXA\%3D\&response-contentdisposition=inline \%3B\%20filename\%3DAdmi nistracion_de_recursos_humanos._El_c.pdf

Cifuentes-Medina, J. E., González-Pulido, J. W., \& González-Pulido, A. (2020). El rol del profesor en la modalidad a distancia. Revista Boletín Redipe, 9(1), 79-90. https://doi.org/10.36260/rbr.v9i1.894

Colocho, F. (2017). La prospectiva como paradigma de planifoificación estratégica gubernamental.). Mediolleno. Recuperado el 10 de julio de 2017 de http://mediolleno.com.sv/politica/laprospectiva-como-paradigma-de-planificacionestrategica-gubernamental
Coll, C. (2004). Psicología de la educación y prácticas educativas mediadas por las tecnologías de la información y la comunicación: una mirada constructivista. Revista Electrónica Sinéctica, 25, 1-24. Recuperado el 10 de julio de http://www.virtualeduca.org/ifd/pdf/cesar-collseparata.pdf

Coll, C. \& Monereo, C. (2008). Psicología de la educación virtual. España: Morata.

Consejo General de Colegios Oficiales de Ingeniería en Informática (CCII). (2015). Estudio nacional sobre la situación laboral de los profesionales del sector TI. CIF: G47670997. Recuperado el 6 de julio de 2017 de http://www.ccii.es/images/ccii/documentos/Info rme_Situacion_Laboral_TI_CCII.pdf

Díaz Barriga, F. (1999). Elaboración del perfil profesional. Metodología de diseño curricular para educación superior. México: Trillas.

García, F. J. 2014. La educación a distancia: Perspectivas y experiencias. Florida: Humboldt International University

Gobierno de México. Plan Nacional de Desarrollo 2019-2024. México. Recuperado el 12 de junio de 2019 de https://www.gob.mx/cenace/acciones-yprogramas/plan-nacional-de-desarrollo-20192024-195029

Hartmann, C. (2011). From urban foresight to urban futures? Potentials and limitations of forward looking activities for integrated urban developement. NA. Recuperado el 11 de julio de 2017 de http://realcorp.at/archive/CORP2011_93.pdf

Instituto Nacional de Estadística y Geografía (INEGI). (2020). Encuesta Nacional de Ocupación y Empleo (ENEO) 2020. Recuperado el 12 de mayo de 2020 de https://www.inegi.org.mx/programas/enoe/15y mas/

Instituto Nacional para la Evaluación de la Educación (INEE). (2015). Acceso y trayectoria en el sistema: tasa neta de cobertura. Recuperado el 12 de julio de 2017 de http://www.inee.edu.mx/bie/mapa_indica/2005/ PanoramaEducativoDeMexico/AT/AT02/2005_ A T02_.pdf 
Instituto Nacional para la Evaluación de la Educación (INEE) (2015). Panorama educativo de México. Indicadores del sistema educativo nacional (SEN). Recuperado el 12 de julio de 2017 de http://www.inee.edu.mx/indicadores_/index.ht $\mathrm{ml}$

International Board of Standards for Training, Performance and Instruction (IBSTPI). (2012). Instructional designer competencies. Recuperado el 07 de julio de 2017 de Recuperado de http://ibstpi.org/introducing-the2012-instructional-design-competencies/

Januszewski, A. (2001). Educational technology: The development of a concept. Libraries Unlimited. Recuperado el 12 de julio de 2017 de https://books.google.com.mx/books?hl=es\&lr= $\& \mathrm{id}=\mathrm{mlZsIIoOaSYC} \&$ oi $=$ fnd $\&$ pg $=$ PR7 $\& \mathrm{dq}=\mathrm{sa}$ ettler,+educational+technology,+2001\&ots=zky WfxxY-h\&sig=fw4CVOSvIrddUAG_ip_3TkfEXQ\#v=onepage \&q=saettler $\% 2 \mathrm{C} \% 20 \mathrm{e}$ ducational $\% 20$ technology $\% 2 \mathrm{C} \% 202001 \& \mathrm{f}=$ fal se

Januszewski, A., \& Molenda, M. (2008). Educational technology: A definition with commentary . New York, NY: Lawrence Erlbaum Associates

Organización para la Cooperación y el Desarrollo Económicos (OCDE). (2014). Panorama de la educación en México. Recuperado el 12 de julio de 2017 de http://www.oecd.org/edu/Mexico- EAG2014-

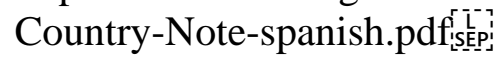

Peña, M. (1993). La dirección de personal (6 $6^{\mathrm{a}}$ ed.). Barcelona: Hispano Europea.

Rivera, R. H. A. \& Malaver, R. M. N. (2010). La importancia de la prospectiva en la sociedad. Universidad \& Empresa, 8(10), 257-270. Recuperado el 14 de julio de 2017 de http://revistas.urosario.edu.co/index.php/empres a/article/view/936
Rothwell \& Kazanas. (2015). Skills, challenges and trends in instructional design, association for talent development. Asociación Internacional de Educación Continua y Entrenamiento (IACET). Recuperado el 4 de julio de 2017 de https://www.iacet.org/default/assets/File/pdfs/2 015\%20ATD_Research_Skills_Challenges_and _Trends_in_Instructional_Design.pdf

Sánchez-Olavarría, C. (2014). Los egresados de comunicación y el mercado laboral: un estudio de trayectorias profesionales. Revista Iberoamericana de Educación Superior, 5(13). Recuperado el 10 de julio de 2017 de https://ries.universia.net/rt/printerFriendly/151/ 322

Senge, P. (2016). La quinta disciplina: el arte y la práctica de la organización abierta al aprendizaje. Buenos Aires, Argentina: Granica.

Sistema Nacional de Información Estadística Educativa (SNIEE) (2017). Estadística $e$ indicadores educativos por entidad federativa. Recuperado el 12 de julio de 2017 de http://www.snie.sep.gob.mx/indicadores_x_enti dad_federativa.html

Tuirán, R. (2012). La educación superior en México, 2006-2012. Un balance inicial. Diario Campus Milenio, 60, 207-226. Recuperado el 8 de julio de 2017 de https://www.ses.unam.mx/curso2016/pdf/28oct-Tuiran-La-educacion-superior-en-Mexico20062012.pdf

Universidad Autónoma del Estado de México. (2020). Tercer informe del plan rector de desarrollo institucional (PRDI) 2017- 2021. Toluca México, México. Recuperado el 06 de junio de 2020 de https://www.uaemex.mx/3informe1721/pdf/terc erinforme.pdf

Universidad Autónoma del Estado de México. (2011). Manual de organización de la Dirección de Educación Continua y a Distancia. Toluca México, México. Recuperado el 09 de julio de 2019 de http://web.uaemex.mx/abogado/doc/0057\%20L inEdCont.pdf 
Universidad Autónoma del Estado de México. (2017). Plan rector de desarrollo institucional (PRDI) 2017- 2021. Toluca México, México. Recuperado el 9 de julio de 2017 de http://www.uaemex.mx/prdi2013-2017/

Vargas, D. (1996). Nueva definición de tecnología instruccional o tecnología educativa. Revista del Centro de Tecnología Educativa, 2(2). Recuperado el 5 de julio de 2017 de http://tecne.uprrp.edu/wp-

content/uploads/2014/09/Tecne-1996-Vol-

II.pdf

Yeaman, A. R., Eastmond Jr, J. N., \& Napper, V. S. (2008). Professional ethics and educational technology. Educational technology: A definition with commentary, 283-326. Recuperado el 10 de julio de 2017 de https://books.google.com.mx/books?hl=es\&lr= \&id=JO3Yc0UuK74C\&oi=fnd\&pg=PA283\&d $\mathrm{q}=$ Yeaman,+Eastmond $+\% 26+$ Napper,+2008\&o ts $=a A v \_$T6nHMt\&sig=BfPgCH3JqsjUPtDJ5fq DIdxTzMo\# $\mathrm{v}=$ onepage $\& \mathrm{q} \& \mathrm{f}=$ false 